Sri Lanka J. Aquat. Sci. 21 (1) (2016): 1-17

\title{
Occurrence of bacteria species responsible for vibriosis in shrimp pond culture systems in Sri Lanka and assessment of the suitable control measures
}

\author{
P.P.M. Heenatigala ${ }^{1 *}$ and M.U.L. Fernando ${ }^{2}$ \\ ${ }^{1}$ Inland Aquatic Resources and Aquaculture Division, National Aquatic \\ Resources Research and Development Agency, Crow Island, Colombo 15, \\ Sri Lanka. \\ ${ }^{2}$ Department of Livestock Production, Faculty of Agricultural Sciences, \\ Sabaragamuwa University of Sri Lanka, Belihuloya, Sri Lanka. \\ *Corresponding author (prajani15@ hotmail.com)
}

\begin{abstract}
Shrimp culture in Sri Lanka is continuously affected by bacterial infections and most symptoms agree with the disease called vibriosis. Therefore a bacteriological study was undertaken in shrimp farms to identify the diversity of pathogenic Vibrio species, favorable environmental conditions for them and sensitivity to antibiotics to control them.

Water and infected animals from shrimp farms of the Western and North Western provinces were screened for Vibrio. Conventional methods were used for presumptive identification of isolated bacteria. Water quality was analyzed by spectophotometric methods. Disk diffusion technique was used to evaluate antibiotic sensitivity. During the study, 40 bacteria isolates belonging to the family Vibrionaceae were recorded. Of those, 24 isolates belonged to Vibrio species which are responsible for vibriosis in shrimps. Those were Vibrio alginolyticus, $V$. parahaemolyticus, $V$. damsela, and $V$. anguillarum. Most frequently isolated species was $V$. parahaemolyticus. All Vibrio isolates were found to be resistant to Ampicillin, Gentamycin, Oxytetracyclin, Chloramphenicol, Trimethoprim and Kanamicin, which are commonly used antibiotics in aquaculture. Water quality conditions indicated that the alkaline $\mathrm{pH}$ conditions and high salinity and ammonia levels favour the occurrence of high vibrio counts.

Results indicate that the application of antibiotics for the control of vibriosis in shrimp farms has limited effectiveness due to the development of resistant bacterial strains and environmental management is the best management intervention that can be used to control this disease.
\end{abstract}

Keywords: antibiotic resistance; shrimp diseases; vibriosis; water quality management 


\section{Introduction}

In the shrimp culture industry in Sri Lanka financial losses due to the infectious diseases has become a major limiting factor in its development. A major concern has been given to the viral infections of shrimps and as a result, their bacterial diseases have received less attention. Vibrio spp. are a part of the natural microflora of wild and cultured shrimps (Sinderman 1990) and the members of the family Vibrionaceae contribute to $60 \%$ of their total bacteria population (Simidu and Tsukamoto 1985). Vibrio bacteria are one of the main pathogenic organisms which cause high mortality in shrimp farming industry. The multitude of infections caused by bacteria belonging to the genus Vibrio is referred as vibriosis. Some of the disease conditions commonly known due to the vibriosis are black shell disease, tail rot, septic hepatopancreatic necrosis, brown gill disease, swollen hindgut syndrome and luminous bacterial disease (Peddie and Wardle 2005). In addition, some Vibrio spp. also act as a primary pathogen to White Spot Syndrome Virus (WSSV) and therefore population of the bacterial species increases with the onset of this viral disease (Jose et al. 2009).

The secondary infection of vibrios in Penaeus monodon occurs due to poor water quality, stress, high stocking density, unstable environmental conditions and virion particles (Karunasagar et al. 1996). In Sri Lanka, poor water quality in shrimp ponds has been identified as a result of unplanned development of inletoutlet canals and therefore effluent water discharged from one shrimp farm is often pumped into the adjoining farm. Thus small-scale developers are generally more affected by self-pollution (Jayasinghe 1999). Since poor water quality is one of the major factors associated with bacterial/vibrio diversity of pond culture systems, assessment of water quality conditions in shrimp ponds is very important to identify the environmental conditions favorable for vibriosis for disease management purposes. Maintaining the pathogenic Vibrio load in an aquaculture system below $1000 \mathrm{CFU} / \mathrm{ml}$ is very important for which is a proper pond bottom and microbial management is necessary (Ganesh et al. 2010).

Shrimp farmers have learned to live with a complex community of microbes and manage them. They mainly use Probiotics and Antibiotics for that (Havenaar et al. 1992). However long-term use and misuse of antibiotics may cause alteration of microbial communities and the generation of drug resistance strains of bacteria (Subasinghe et al. 2000). Consequently, antimicrobial agents persist in sediment and aquatic environments, leading to deteriorated environmental conditions and conferring antimicrobial resistance to the sediment bacteria. Of particular concern is the indiscriminate use of antibiotics leading to the development of multiple-antibiotic resistant pathogenic bacteria in shrimps and humans (Zanetti et al. 2001). In this case, shrimps could serve as delivery vehicles of antimicrobial resistance to pathogenic bacteria from aquatic environments to humans and from one country to another (Zanetti et al. 2001). Accumulation of drug residues in the cultured commodity upon harvest is another problem evolved due to the usage of chemicals (Subasinghe 2009). 
Therefore, investigations about Vibrio diversity, environmental conditions favourable to them and usage of antibiotics in shrimp pond culture systems to control vibriosis will generate useful information for the efficient disease control and management practices in the country. Finally this will help to minimize the disease outbreaks leading to the sustainability of the shrimp culture industry.

\section{Materials and Methods}

\section{Study Area}

The study was carried out in Western and North Western coastal belt of Sri Lanka covering Chilaw, Puttalam and Kalpitiya areas where the shrimp culture is popular.

\section{Sampling criteria}

The study was carried out for two culture operations during 2010 in semi intensive shrimp (Penaeus monodon) culture ponds. The water, sediments and hemolymph samples were collected biweekly in every month throughout the culture operation.

\section{Water}

For bacteriological assessment, water samples $(n=62)$ were collected for the sterilized McCartney bottles, just below from the water surface. Necessary precautionary measures were undertaken to minimize the contamination through handling. For water quality assessment, water samples $(n=62)$ were collected separately in plastic bottles.

\section{Hemolymph}

Hemolymph samples $(n=15)$ were collected to sterilized syringes from an identified diseased shrimp (Tail rot).

\section{Sediment}

Sediment samples $(\mathrm{n}=27)$ were collected using a PVC pipe. The untouched central portion of the collected sample was aseptically transferred into new polythene bags using a sterile spatula for further bacteriological analysis.

All samples collected were placed in ice and immediately transported to the laboratory for analysis within 24 hours.

\section{Bacterial counts}

To quantify the Total Vibrio Counts (TVC) in pond water, collected water samples were serially diluted using sterile $\mathrm{NaCl}$ blanks. The blanks were prepared with $9 \mathrm{ml}$ of $2 \% \mathrm{NaCl}$ solution and sterilized in an autoclave at $15 \mathrm{lbs}$. and $121^{\circ} \mathrm{C}$ for $15 \mathrm{~min}$. 
To enumerate TVC, $1 \mathrm{ml}$ sample from desired dilution was pipetted out into a sterile petridish. To this, $15-20 \mathrm{ml}$ melted and cooled Thiosulfate-Citrate-Bile SaltsSucrose (TCBS) agar medium (Hi-media, Mumbai) was poured and mixed thoroughly. Plates in duplicate were incubated in an inverted position at the room temperature $\left(30^{\circ} \pm 2^{\circ} \mathrm{C}\right)$ for 24 hours. The plates containing viable bacterial colonies were counted and were expressed as Colony Forming Units $(\mathrm{CFU} / \mathrm{ml})$ for water sample.

\section{Isolation of Vibrio}

All the samples (pond water, sediments and heamolymph of diseased shrimp) were diluted serially and $0.1 \mathrm{ml}$ aliquots were spread plated onto TCBS agar medium (Hi Media, Mumbai) with $2 \% \mathrm{NaCl}$ and incubated at $30^{\circ} \pm 2^{\circ} \mathrm{C}$ for 24 hours. The morphology and the number of colonies on TCBS were recorded for all samples.

\section{Obtaining pure cultures}

Most dominant yellow green and blue green colonies from each sample were selected and sub-cultured $2-3$ times on TSA with $2 \% \mathrm{NaCl}$ and incubated at $30^{\circ} \pm 2^{\circ}$ C for 24 hours to obtain pure cultures.

\section{Species identification}

Twenty three biochemical characters were assessed according to the diagnostic scheme for Vibrio species given in Vos et al. (2009). The pure cultures obtained were grown on Trypticase Soy Agar (TSA, Hi Media, Mumbai) for approximately 24 hours to subject the biochemical reactions and tests which included motility, oxidase production, Gram's staining, fermentation of sugars, amino acid decarboxylase activity, nitrate reduction, sensitivity to $\mathrm{O} / 129$, urease production, Gelatine degradation and MR-VP reaction, Indole production, growth under different temperatures, $\mathrm{NaCl}$ tolerance etc. All biochemical test media were supplemented with $2 \% \mathrm{NaCl}$ and incubated at $30^{\circ} \mathrm{C}\left( \pm 2{ }^{\circ} \mathrm{C}\right)$ for 24 hours. All the experimental isolates and the results were taken after $24 \mathrm{~h}$ at $30^{\circ} \mathrm{C}$ unless otherwise indicated. Results obtained during the bio chemical tests are shown in Table 1.

\section{Antibiotic Sensitivity test (AST)}

Kirby-Bauer disk-diffusion technique (Bauer et al. 1966) was used to assess antibiotic sensitivity of the bacterial isolates. Muller Hington Agar (Hi-Media, Mumbai) was used as media.

Six routinely used broad-spectrum antibiotics contained impregnated discs (Hi-Media, Mumbai) of Ampicillin $(10 \mu \mathrm{g})$, Gentamycin $(10 \mu \mathrm{g})$, Oxytetracyclin $(30 \mu \mathrm{g})$, Chloramphenicol $(30 \mu \mathrm{g})$, Trimethoprim $(5 \mu \mathrm{g})$ and Kanamicin $(30 \mu \mathrm{g})$ were taken to assess the antibiotic sensitivity of the isolates. 
Table 1. Morphological and biochemical characteristics of identified Vibrio isolates from shrimp farms. V.al. - Vibrio alginolytics; V.an. - V. anguillarum; V.da. - V. damsela; V.pa. - V. paraheamalyticus

\begin{tabular}{|c|c|c|c|c|c|}
\hline $\begin{array}{l}\text { Sample } \\
\text { No. }\end{array}$ & Test & V.al. & V.an. & V.da. & V.pa. \\
\hline 1 & Gram stain & - & - & - & - \\
\hline 2 & Shape & $\mathrm{R}$ & $\mathrm{R}$ & $\mathrm{R}$ & $\mathrm{R}$ \\
\hline 3 & Motility & + & + & + & + \\
\hline 4 & Cytochrome oxidase & + & + & + & + \\
\hline 5 & Catalase & + & + & + & + \\
\hline 6 & $\mathrm{O} / \mathrm{F}$ test & $\mathrm{F}$ & $\mathrm{F}$ & $\mathrm{F}$ & $\mathrm{F}$ \\
\hline \multirow[t]{8}{*}{7} & Acid production from carbohydrates & & & & \\
\hline & a. Glocose & + & + & + & + \\
\hline & b. Sucrose & + & + & - & - \\
\hline & c. Lactose & - & - & - & - \\
\hline & d. Mannitol & + & + & + & + \\
\hline & e. Maltose & + & + & + & + \\
\hline & f. Salicin & + & - & - & - \\
\hline & g. Xylose & - & - & + & - \\
\hline 8 & Gas from glucose & - & - & - & - \\
\hline 9 & $\mathrm{H}_{2} \mathrm{~S}$ production & - & - & - & - \\
\hline 10 & Citrate utilization & + & + & + & + \\
\hline 11 & Aesculin hydrolysis & - & - & - & - \\
\hline 12 & Gelatinase & - & + & + & + \\
\hline 13 & Nitrate reduction & + & + & + & + \\
\hline 14 & Methyl red test & + & + & + & + \\
\hline 15 & Voges Proskauer test & + & + & + & - \\
\hline 16 & Indole production & + & + & - & - \\
\hline \multirow[t]{4}{*}{17} & Decarboxylation of: & & & & \\
\hline & a. Arginine & - & + & + & - \\
\hline & b. Lysine & + & - & $\mathrm{V}$ & + \\
\hline & c. Ornithine & + & - & - & + \\
\hline 18 & Growth at $20^{\circ}$ to $30^{\circ} \mathrm{C}$ & + & + & + & + \\
\hline 19 & Growth at $37^{\circ} \mathrm{C}$ & - & - & - & - \\
\hline 20 & Growth at $42^{\circ} \mathrm{C}$ & - & - & - & - \\
\hline \multirow[t]{7}{*}{21} & $\mathrm{NaCl}$ tolerance: & & & & \\
\hline & a. $0 \%$ & - & - & - & + \\
\hline & b. $2 \%$ & + & + & + & + \\
\hline & c. $4 \%$ & + & + & + & + \\
\hline & d. $6 \%$ & + & $\mathrm{V}$ & $\mathrm{V}$ & + \\
\hline & e. $8 \%$ & - & - & $\mathrm{V}$ & + \\
\hline & f. $10 \%$ & - & - & $\mathrm{V}$ & + \\
\hline 22 & TCBS agar & $\mathrm{Y}$ & $\mathrm{Y}$ & - & $\mathrm{G}$ \\
\hline
\end{tabular}

(+ : Positive; - : Negative; F : Fermentative; R : Rods; Y : Yellow colonies; G :

Green colonies; V : Variable among strains) 
The diameters of the inhibition zones of the each tested antibiotic disk were measured and interpreted as sensitive (S) or intermediate sensitive (I) or resistant (R) based on National Committee for Clinical Laboratory Standards (NCCLS 1998) provided by manufacturer of the impregnated antimicrobial discs.

\section{Multiple Antibiotic Resistant (MAR) Index}

When there are more than three antibiotics showing resistance, Multiple Antibiotic Resistant (MAR) index of the isolate can be calculated (Riaz et al. 2011). MAR index is considered as a good tool for risk assessments and this also gives an idea of the number of bacteria showing antibiotic resistance in the risk zone in the routine susceptibility testing. MAR index also recommends that all isolates, somehow, originated from the environment where antibiotics are over-used. The value of MAR index (0.200) differentiates the low and high risk. If the value is between 0.200 and 0.250 , it becomes a very risky phase where there are equal chances that MAR may fall in the high risk and low risk phases (Krumperman 1983).

From the results obtained, MAR index of the identified pathogens were calculated. The MAR Index of an isolate is defined as $a / b$, where a represents the number of antibiotics to which the isolate was resistant and $b$ represents the number of antibiotics to which the isolate was subjected (Riaz et al. 2011).

\section{Water Quality}

Temperature, $\mathrm{pH}$, Dissolved Oxygen (DO), $\mathrm{NH}_{3}$ (Ammonia), Salinity and Sulfide were analyzed in collected water samples. $\mathrm{pH}, \mathrm{DO}$ and salinity were analyzed in the field using portable meters $(\mathrm{pH} 210$ - HANNA, HACH Sension 6, ATAGO MASTE-S/MillCK). $\mathrm{NH}_{3}$ and Sulfide were analyzed by DR 4000 Spectrophotometer using powder pillows (DR - 4000, HACH).

\section{Statistical analysis}

Pearson correlation analysis was carried out to find out whether there are any significant influences of water quality parameters on TVC in pond culture system. SPSS version 16.0 statistical package was used for statistical analysis.

\section{Results}

\section{Species Diversity}

During the study 40 bacteria isolates belong to the family Vibrionaceae were recorded and among them 24 were presumptively identified as Vibrio spp. responsible for vibriosis in shrimps. As shown in Table 1, according to the biochemical and physiological characteristic of the diagnostic scheme for Vibrio species described by Vos et al. (2009), all those Vibrio isolates belonged to 4 
species. Those were $V$. alginolyticus, $V$. parahaemolyticus, $V$. damsela, and $V$. anguillarum. The species composition of the isolates is given in Table 2 and Figure 1. Most frequently isolated species was $V$. parahaemolyticus.

Table 2. Vibrio isolates of different species as percentages

\begin{tabular}{llr}
\hline Sample & Identified bacteria & $\%$ \\
\hline Pond water & V.parahaemolyticus & 55.5 \\
& V.alginolyticus & 27.7 \\
& V. damsela & 5.6 \\
& V.anguillarum & 5.6 \\
Pond & Unidentified Vibrio & 5.6 \\
Sediments & V. parahaemolyticus & 25.0 \\
& V.alginolyticus & 50.0 \\
Shrimp & Unidentified Vibrio & 25.0 \\
hemolymph & V.alginolyticus & 100.0 \\
\hline
\end{tabular}

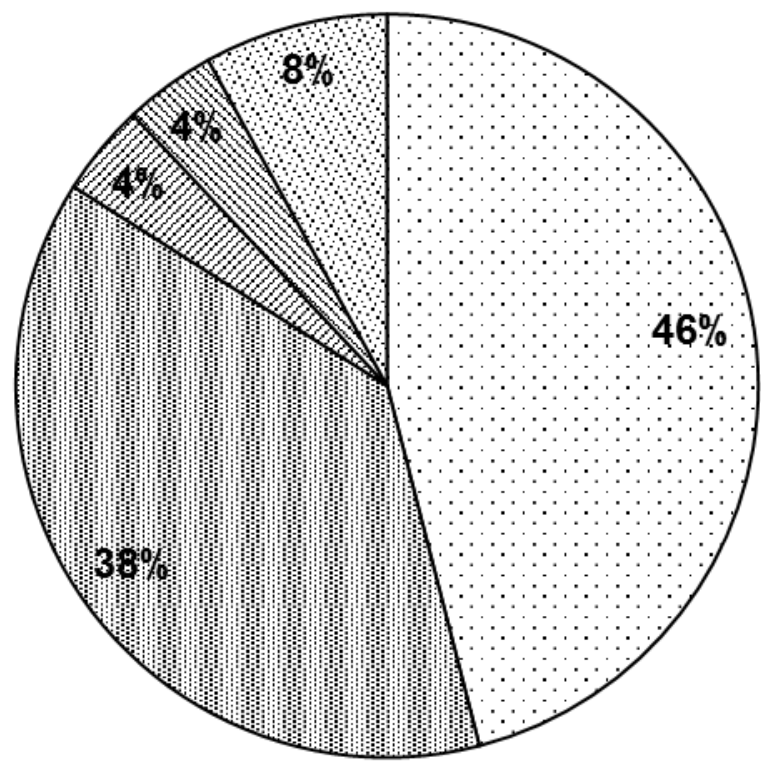
$\square$ V. paraheamolyticus
圈 V. alginolyticus
$\square$ V. damsela
图 $V$. anguillarum

\section{⿴囗十 Unidentified Vibrio}

Figure 1. Percentages of different bacteria species 


\section{Microbiological parameters}

Total Vibrio counts (TVC) in the pond water where the pathogenic Vibrio species were isolated ranged from 0 to $5 \times 10^{3} \mathrm{cfu} / \mathrm{ml}$.

Water quality parameters and their correlation with TVC

Water quality parameters in shrimp ponds and their optimal ranges for shrimp culture are given in Table 3 .

Table 3. Mean \pm SD values of the water quality parameters of shrimp ponds. Optimum ranges are also given here.

\begin{tabular}{lcc}
\hline Parameter & Mean \pm SD & $\begin{array}{c}\text { Optimum ranges } \\
\text { for shrimps* }\end{array}$ \\
\hline $\mathrm{pH}$ & $7.7 \pm 0.5$ & $7.5-8.5$ \\
Dissolved oxygen $(\mathrm{mg} / \mathrm{l})$ & $7.1 \pm 2.2$ & $5.1-5.9$ \\
Alkalinity $(\mathrm{mg} / \mathrm{l})$ & $122.6 \pm 37.9$ & $40-160$ \\
Salinity $(\mathrm{ppt})$ & $27.7 \pm 9.3$ & $15-25$ \\
$\mathrm{NO}_{2}^{-}(\mathrm{mg} / \mathrm{l})$ & $0.032 \pm 0.029$ & $<1$ \\
$\mathrm{NO}_{3}^{-}(\mathrm{mg} / \mathrm{l})$ & $6.3 \pm 6.8$ & $<1$ \\
$\mathrm{NH}_{3}(\mathrm{mg} / \mathrm{l})$ & $2.5 \pm 4.0$ & 0.5 \\
Sulfide $(\mu \mathrm{g} / \mathrm{l})$ & $44.4 \pm 44.2$ & $<0.03$ \\
\hline
\end{tabular}

*Sources: Chiu (1988); Boyd (1995); Matias (2002); Ganesh et al. (2010).

Correlation of TVC with selected water quality parameters (Pearson correlation coefficient; Table 4) indicated that none of the correlations were significant at 0.05 probability level. Although not statistically significant, there were positive influences of Ammonia, $\mathrm{pH}$, Salinity and Alkalinity on TVC while dissolved oxygen had negative influence on TVC in shrimp culture ponds.

Table 4. Pearson correlation coefficient of Total Vibrio counts (TVC) with different water quality parameters $(\mathrm{df}=24$; None of the correlations are significant at 0.05 probability level.).

\begin{tabular}{lr}
\hline Water quality parameter & Correlation coefficient \\
\hline $\mathrm{pH}$ & 0.267 \\
Dissolved oxygen & -0.163 \\
Alkalinity & 0.314 \\
Salinity & 0.384 \\
$\mathrm{NO}_{2}{ }^{-}$ & 0.111 \\
$\mathrm{NO}_{3}$ & 0.064 \\
$\mathrm{NH}_{3}$ & 0.040 \\
Sulfide & 0.125 \\
\hline
\end{tabular}


Antibiotic Resistance

Results obtained from antibiogram showed that the majority of Vibrio isolates were resistant, few were intermediate resistant and none were sensitive to the antibiotics tested (Figure 2). From the Vibrio spp. isolated, $100 \%$ are resistant to Oxytetracycline (0-30), Ampicillin (Am-10), Kanamycin (K-30), Gentamicin (G10 ), and Trimethoprim (TR -5 ), only $25 \%$ showed intermediate sensitivity and $75 \%$ showed resistance to Chloramphenicol.

Antibiotic Resistance

All isolates (100\%) showed MAR index higher than 0.2 (Figure 3). Bacteria with MAR under 0.2 are considered as originated from high risk sources where antibiotics are often used.

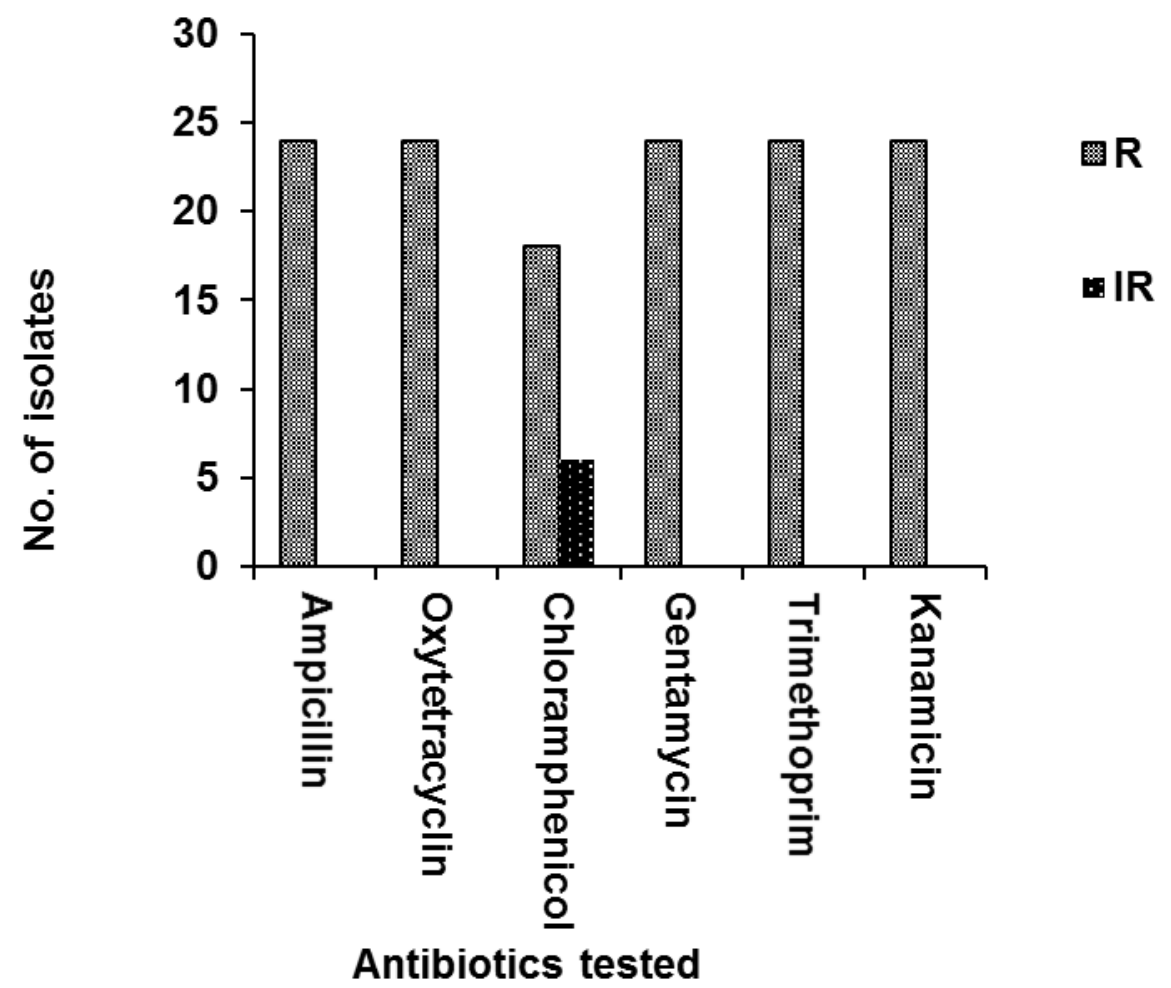

Figure 2. The sensitivity pattern of the isolated Vibrio forms to different antibiotics. None was sensitive to any of the antibiotics tested. 


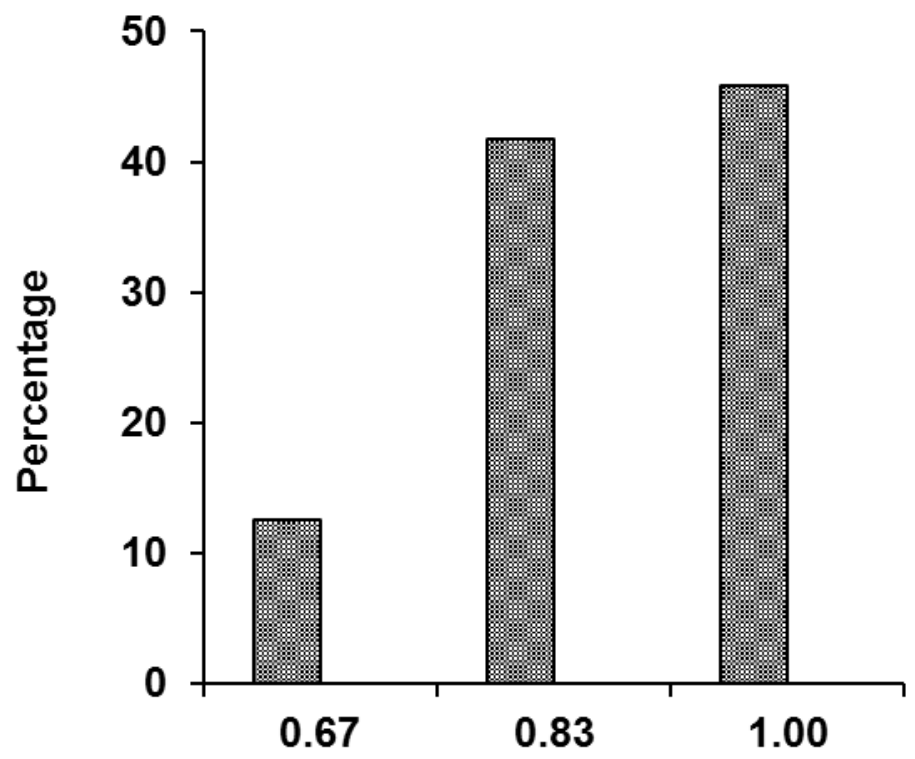

MAR lindex

Figure 3. Distribution of MAR index values within identified pathogen bacteria.

\section{Discussion}

In shrimp culture ecosystems, pathogenic bacteria play a negative role as they compete with shrimps for food and oxygen, while causing stress and diseases (Moriarty 1997). Generally gram-negative bacteria were found to be the dominant forms in the shrimp culture ponds (Sung et al. 2003). Sindermann (1979) has pointed out that Vibrio spp. are the major disease causing bacteria normally found in the environment (Yasuda and Kitao 1980; Sharmila et al. 1996).

More than 30 pathogenic Vibrio spp. have been identified in shrimp culture systems (Farmer 1992). However, in the present study only four Vibrio species viz., $V$. alginolyticus, $V$. parahaemolyticus, $V$. damsela and $V$. anguillarum were identified. In a previous study, V. cholera, V. metschnikovii, V. parahaemolyticus, $V$. carchariae, $V$. harveyi, $V$. vulnificus, $V$. damsela, $V$. mimicus, $V$. furnissii and $V$. fluvialis have been recorded in marine shrimps of Sri Lanka (Jayasinghe et al. 2008). However, only V. parahaemolyticus and V.damsela of those were recorded in the present study. This may be due to variation in the season and condition of sea water and soil in the area. However, opportunistic species may be expected to vary from one geographical area to another and from one hatchery to another within a country as well as in different countries. 
$V$. alginolyticus, identified in this study was recorded as a species with one of the most virulent pathogenic strains and $V$. anguillarum has been recorded as one of most economically serious pathogenic Vibrio species in marine environment (Larsen and Olsen 1991; Jayasree 2000; Chythanya et. al. 2002). Among the Total Heterotropic Bacteria (THB) in shrimp ponds, V. parahaemolyticus plays a vital role (Ruangpan and Kitao 1991) as they damage water quality causing diseases and mortality to the shrimp as primary and secondary pathogens. Shrimp culture operations had faced serious viral disease outbreaks and mortality of shrimp when many populations of THB and $V$. parahaemolyticus were observed (Ganesh et al. 2010). Some studies has proven that $V$. parahaemolyticus could act as a primary pathogen to White Spot Disease (WSD) as population of the bacterial species increases with the onset of this viral disease. Also according to Jose et al. (2009), these bacterial species might have facilitated WSSV to enter the chitinous body of shrimp due to its chitinolytic activity.

In aquaculture systems the pathogenic Vibrio load should be kept under control (below $1000 \mathrm{CFU} / \mathrm{ml}$; Ganesh et al. 2010). The present study revealed that TVCs of some tested ponds were higher than the above limit. Low water exchange in farms to prevent water contamination through intake water and utilization of high amount of organic manure, inorganic fertilizer, high stocking density, feed waste, fecal matter, algal bloom and human interference are the main reasons for this situation (Moriarty 1997; Lloberra et al. 1991).

Due to unplanned development of inlet-outlet canals of the shrimp farm system in Sri Lanka, the effluent water discharged from one shrimp farm is often pumped into the adjoining farm. Discharge of pond effluent has led to deterioration in water quality in the main water sources. Farms take in water and discharge their effluent into the same water source and no treatment procedure is practiced. The inter-connected lagoon complex between Chilaw and Puttalam that serves as the main source of brackish water for the farms is apparently polluted and the risk of disease outbreaks is increasing.

Higher proportion of total Vibrio in grow-out ponds implies that microbial heterogeneity in there ponds is low. A relatively high level of microbial heterogeneity in the culture system often helps to reduce the vulnerability of farmed animals to opportunistic colonization of bacteria (Olafsen 2001). This has to be based, however, on the reduction of potentially pathogenic opportunistic bacteria. It is a general rule in aquaculture practices that a high number of Vibrio spp. in the surface water of the facility poses a potential threat to the farmed animals, since various Vibrio species were proven to cause infectious disease in the farmed marine animals (Diggles et al. 1999).

\section{Water Quality}

According to the water quality data obtained in this study, alkaline $\mathrm{pH}$ conditions, high salinity and high ammonia and sulfide levels as well as low DO levels appear to create favorable conditions for the growth of Vibrio spp. in shrimp ponds. As vibriosis is a stress induced disease in shrimp (Jayasree 2000) and most pathogenic 
Vibrio spp. are opportunistic pathogens, they become virulent in response to environmental effects that favour their survival over that of the host (Guzman et al. 2001). Present study revealed that the salinity levels of the majority of studied ponds were not within recommended range (15-25 ppt; Boyd 1995). The reason may be due to poor farm management practices such as those associated with water exchange. Salinity is the most important factor influencing many functional responses such as metabolism, growth, migration, osmotic behaviour and reproduction of the organisms. In previous studies, significant positive correlation of salinity has been recorded with TVC (Abraham and Sasmal 2009) and salinity dependent distribution of luminous Vibrio spp. in shrimp farms (Abraham et al. 2003).

The critical limit of ammonia for shrimp pond is $<0.5 \mathrm{mg} / \mathrm{l}$ (Matias et al. 2002). Ammonia is produced due to the decomposition of nitrogenous organic wastes. Nitrogenous organic wastes derive from uneaten feeds and excretion of shrimps. The concentration of $\mathrm{NH}_{3}-\mathrm{N}$ is known to be positively correlated with the amount of food wastage and the stocking density. Present study revealed that some $\mathrm{NH}_{3}$ levels were higher than the critical level, probably due to higher stocking densities and low water exchange in farms. Good water quality throughout of the culture period is essential for high shrimp growth and survival. This study showed that most water quality parameters were not in the optimum level, which may be due to poor farm practices. Farmers should maintain water quality of ponds in proper manner in order to improve farm performances.

According to Palaniappan (1982), in any aquatic system, environmental parameters such as temperature, salinity, $\mathrm{pH}$ and dissolved oxygen play a foremost role in the distribution of bacteria. According to Phuoc et al. (2009) occurrence of bacterial diseases is determined by two main factors: physical stressors and other pathogens. Most outbreaks of shrimp vibriosis happen either in combination with physical stress factors or following primary infections with other infections (Sung et al. 2001). Liu and Chen (2004) showed that shrimp exposed to Ammonium stress prior to challenge showed higher susceptibility to Vibrio spp.

\section{Antibiotic sensitivity}

The overuse of antibiotics can result in the development of resistance strains of bacteria in aquaculture systems. The more frequently a drug is administered, the greater the percentage of the bacteria in the shrimp facility that will be antibioticresistant (Romero et al. 2012).

Management practices such as high stocking densities, chemical treatment, grain-based artificial diet, accumulation of organic wastes in the form of excess feed, excreta and dead plankton have residual influence on the antibiotic resistance of aquatic bacteria (McPhearson et al. 1991). Daily feeding of antibiotics with feed as prophylactics, encourages antibiotic resistance in the ponds. Shrimp eat a low percentage of their feed and the antibiotics it is laced with, end up in the water and muddy bottom. Many antibiotics are not biodegradable and persist in the 
surrounding environment, where they continue to fight against bacteria that continue to develop resistance (Romero et al. 2012).

Previous studies have shown that the isolated colonies of Vibrio spp. from the hepatopancreas, gills, carapace and flesh of disease infected adults of $P$. monodon were highly sensitive to Chloramphenicol $(10 \mu \mathrm{g}$ and $30 \mu \mathrm{g})$ and Tetracycline $(30 \mu \mathrm{g})$ and moderately sensitive to Streptomycin $(25 \mu \mathrm{g})$ and Oxytetracycline $(30 \mu \mathrm{g})$ when compared to Furazolidone $(50 \mu \mathrm{g})$, Erythromycin (15 $\mu \mathrm{g})$ and Sulphafurazole $(30 \mu \mathrm{g})$ (Ariyawansa et al. 1999). When those results are compared with the present study, it is evident that the bacterial sensitivity for the Chloramphenicol has changed from sensitive to moderate sensitive and/or resistant and that for the Oxytetracyclin it has changed from moderately sensitive to resistant. These changes may be due to the increased use of antibiotics.

Majority of bacteria isolated in the present study have developed resistance against antibiotics used. Acquired antibiotic resistance in bacteria is generally mediated by extra chromosomal plasmids and is transmitted to next generation (vertical gene transfer) and also exchanged among different bacterial population (horizontal gene flow) (Manjusha et al. 2005). Therefore, resistant genes can be passed to next generation of bacteria.

This study therefore shows the alarming trend of Vibrio spp. becoming antibiotic resistant, thus highlighting the danger of complete affectivity of antibiotics against these species in the future. Considering Vibrio as a genus of human pathogens as well, the quick resistance development in aquatic environment poses a big threat to human health also.

\section{Acknowledgements}

Thanks are due to the shrimp Industry personnel for providing samples and required information. We are grateful to Professor J.M.P.K. Jayasinghe, Wayamba University of Sri Lanka for his valuable guidance. National Aquatic Resources Research and Development Agency is acknowledged for facilitating this study.

\section{References}

Abraham T.J. \& D. Sasmal 2009. Influence of Salinity and Management practices on the shrimp (Penaeus monodom) production and bacterial counts of modified extensive brackish water ponds. Turkish Journal of Fisheries and Aquatic Science 9: 91-98.

Abraham T.J., S.A. Shanmugam, R. Palaniappan \& K. Dhevendran 2003. Distribution and abundance of luminous bacteria with special reference to shrimp farming activities. Indian Journal of Marine Science 32 (3): 208213.

Ariyawansa K.W.S., J.M.P.K. Jayasinghe, N.D. Wijengra \& K. Hettiarachchi 1999. Antibiotic sensitivity of bacterial isolates from Penaeus monodon cultured in semi intensive systems. Proceeding of $5^{\text {th }}$ Annual Scientific Sessions of Sri Lanka Association for Fisheries and Aquatic Resources 34 p. 
Bauer A.W., W.M.M. Kirby, J.C. Sherris \& M. Turck 1966. Antibiotic susceptibility testing by a standardized single disk method. American Journal of Clinical Pathology 36: 493-496.

Boyd C.E. 1995. Chemistry and efficacy of amendments used to treat water and soil quality imbalances in shrimp ponds. pp. 183-199. In: Broody, C.L. \& J.S. Hopkins (eds), Swimming through Troubled waters. Proceedings of the Special Session on Shrimp Farming, Aquaculture 1995, World Aquaculture Society, Baton Rouge, Los Angeles.

Chiu Y.N. 1988. Water quality management for intensive prawn ponds. In: Y.N. Chiu, L.M. Santos \& R.O. Juliano (eds.), Technical Considerations for the Management and Operation of Intensive Prawn Farms. UP Aquaculture Society, Iloilo city. 102-129 pp.

Chythanya R., I. Karunasagar \& I. Karunasagar 2002. Inhibition of shrimp pathogenic vibrios by a marine Pseudomonas I-2 strain. Aquaculture 208 (1-2): 1-10.

Diggles B.K., J. Carson, P.M. Hine, R.W. Hickman \& M.J. Tait 1999. Vibrio species associated with mortalities in hatchery reared turbot (Colistium nudipinnis) and brill (C. guntheri) in New Zealand. Aquaculture 183: 1 -12.

Farmer J.J. III 1992. The family of Vibrionaceae. pp. 2938-2951. In: Balows, A., H.G. Trüper, M. Dworkin, W. Harder \& K.H. Schleifer (eds), The Prokaryotes: A Handbook on the Biology of Bacteria: Ecophysiology, Isolation, Identification, Applications, Volume 4. 2nd edition. SpringerVerlag. New York.

Ganesh E.A., S. Das, K. Chandrasekar, G. Arun. \& S. Balamurugan 2010. Monitoring of total heterotrophic bacteria and Vibrio spp. in an aquaculture pond. Current Research Journal of Biological Sciences 2(1): 48-52.

Guzmán A.G., R. Vázquez-Juárez. \& F. Ascencio 2001. Differences in the susceptibility of American white shrimp larval substages (Litopenaeus vannamei) to four Vibrio species. Journal of Invertebrate Pathology 78: 215-219.

Havenaar, R., T. Brink, B. Huis \& J.H.J. Veld 1992. Selection of strains for probiotic use. In: Fuller, R. (ed.), Probiotics: The Scientific Basis. Chapman and Hall, London. 209-224 pp.

Jayasinghe, C.V.L., S.B.N. Ahmed \& M.G.I.U. Kariyawasam 2008. The isolation and identification of Vibrio species in marine shrimps of Sri Lanka. Journal of Food and Agriculture 1 (1): 36-44.

Jayasinghe, J.M.P.K. 1999. Shrimp culture in Sri Lanka: Key issues in sustainability and research. In: Towards Sustainable shrimp culture in Thailand and the Region. Australian Center for International Agricultural Research, Canberra 48-51 pp.

Jayasree, L. 2000. Identification of immune cells interacting with Vibrio spp. and its in vitro post-phagocytic killing mechanism of haemocytes in the penaeid shrimp, Penaeus indicus H. Milne Edwards. Journal of Fish Diseases. 32(4): 359-365. 
Jose, P., F. Li, J. Zhang, B. Wang, C. Zhao \& J. Xiang 2009. Molecular characterization and effect of RNA interference of retinoid $\mathrm{X}$ receptor (RXR) on E75 and chitinase gene expression in Chinese shrimp Fenneropenaeus chinensis. Comparative Biochemistry and Physiology Part B: Biochemical and Molecular Biology 153(1): 121-129.

Karunasagar I., S.K. Otta, I. Karunasagar \& K. Joshua 1996. Applications of Vibrio vaccine in shrimp culture. Fishing Chimes 14: 205-254.

Krumperman P.H. 1983. Multiple antibiotic resistance indexing Escherichia coli to identify risk sources of fecal contamination of foods. Applied environmental Microbiology. 46:165-170.

Larsen J.L. \& J.E. Olsen 1991. Occurrence of plasmids in Danish isolates of Vibrio anguillarum Serovars O1 O2 and association of plasmids with phenotypic characteristics. Applied Environmental Microbiology 57: 2158-2163.

Lavilla-Pitigo C.R.M., C.L. Baticados, E.R. Cruze Lacierda \& L.D. de La Pena 1990. Occurrence of luminous bacterial disease of Penaeus monodon larvae in the Philippines. Aquaculture 91: 1 -3.

Liu C.H. \& J.C. Chen 2004. Effect of ammonia on the immune response of white shrimp Litopenaeus vannamei and its susceptibility to Vibrio alginolyticus. Fish and Shellfish Immunology 6: $321-134$.

Lloberra, A.T., M.L. Bulalacao, \& A. Tan 1991. Effect of farming phase and inplant processing on the microbiological quality of prawn (Penaeus monodon). 15 pp. In: Indo-Pacific Fishery Commission Working Party on Fish Technology and Marketing 19(22), Food and Agriculture Organization of the United nations, Rome.

Manjusha, S., G.B Sarita, K.K. Elas, and M. Chandrasekaran 2005. Multiple antibiotic resistances of Vibrio isolates from coastal and brackish water areas. American Journal of Biochemistry and Biotechnology 1(4): 201-206.

Matias, H.B., F.M.Yusoff1, M. Shariff, \& O. Azhar, 2002. Effects of commercial microbial products on water quality in tropical shrimp culture ponds. Asian Fisheries Science 15: 239-248.

McPhearson, M.R., A. De Paola, P.S. Zywno, L.M. Motes \& M.A Guarino 1991. Antibiotic resistance in gram-negative bacteria from cultured catfish and aquaculture ponds. Aquaculture 99: 203-211.

Moriarty, D.J.W., 1997. The role of microorganisms in aquaculture ponds. Aquaculture 151: 333-349.

NCCLS 1998. Performance Standards for Antimicrobial Susceptibility Testing: Eighth Informational Supplement M100-S8. NCCLS, Wayne, PA.

Olafsen, J.A. 2001. Interaction between fish larvae and bacteria in marine aquaculuture. Aquaculture 200: 223-257.

Palaniappan. R., 1982. Studies on the micro flora of the Prawn Penaeus indicus, Milne Edwards (Crustacea, Decapoda, Penaediae) with reference to its digestive system. Ph.D Thesis, Annamalai University, Annamalai Nagar, Chidambaram.

Peddie, S. \& R. Wardle 2005. The impact and control of vibriosis in shrimp culture worldwide. Aquaculture Health International. (2): 4-5. 
Phuoc L.H, M. Corteel, N.C. Thanh, H. Nauwynck, M. Pansaert, V. Alday- Sanz, W. V. Broeck, P. Sorgeloos \& P. Bossier 2009. Effect of dose and challenge routs of Vibrio spp. On co infections with white spot syndrome virus in Penaeus vannamei. Aquaculture 290: 61-68.

Riaz, S., M. Faisal \& S. Hasnain 2011. Antibiotic susceptibility pattern and multiple anti biotic resistances (MAR) calculation of extended spectrum $\beta$-lactamase (ESBL) producing Escherichia coli and Klebsiella species in Pakistan. African Journal of Biotechnology 10(33): 6325-6331.

Romero, J., C.G. Feijoó \& P. Navarrete 2012. Antibiotics in aquaculture - Use, abuse and alternatives. 159-198 pp. In: (Carvalho, E., G.S. David \& R.J. Silva eds), Health and Environment in Aquaculture. ISBN: 978-953-510497-1, In Tech, Rijeka, Croatia.

Ruangpan, L. \& T. Kitao 1991. Vibrio bacteria isolated from black tiger shrimp Penaeus monodon Fabricius. Journal of Fish Diseases 14: 383-388.

Sharmila, R., T.J. Abraham \& V. Sundararaj 1996. Bacterial flora of semi-intensive pond-reared Penaeus indicus (H. Milne Edwards) and the environment. Journal of Aquaculture in the Tropics 11: 193-203.

Simidu, V. \& K. Tsukamoto 1985. Habitat segregation and biochemical activities of marine members of the family Vibrionaceae. Applied and Environmental Microbiology 105: 781-790.

Sindermann, C.J. 1979. Pollution-associated disease and abnormalities of fish and shell fish-A review. Fisheries Bulletin 76(4): 717-749.

Sindermann, C.J. 1990. Principal Diseases of Marine Fish and Shellfish. Volume 2. 2nd edition. Academic Press, New York.

Subasinghe R. 2009. Disease control in aquaculture and the responsible use of veterinary drugs and vaccines: the issues, prospects and challenges. In: Rogers C. (ed.), Basurco B. (ed.). The use of veterinary drugs and vaccines in Mediterranean aquaculture. Zaragoza 2009: 5-11.

Subasinghe, R.P., U. Barg, \& A. Tacon 2000. Chemicals in Asian aquaculture: Need, usage, issues and challenges. 1-5 pp. In: J.R. Authur, C.R. LavillaPitogo, R.P. Subasinghe (eds) Proceeding of the Meeting on the use of Chemicals in Aquaculture in Asia, 20-22 May 1996. SEAFDEC, Tigbauna, Iloilo.

Sung, H-H., S-C. Lin, W-L. Chen, Y-Y. Ting \& W-L.Chao 2003. Influence of Timsen $^{\mathrm{TM}}$ on Vibrio populations of culture pond water and hepatopancreas and on the hemocytic activity of tiger shrimp (Penaeus monodon). Aquaculture 219(1-4): 123-133.

Sung, H-H, S-F. Hsu, C-K. Chen, Y-Y. Ting \& W-L. Chao 2001. Relationships between disease outbreaks in cultured tiger shrimps (Penaeus monodon) and the composition of Vibrio communities in pond water and shrimp hepatopancreas during cultivation. Aquaculture 192: 101-110.

Vos, P., G. Garrity, D. Jones, N.R. Krieg, W. Ludwig, F.A. Rainey, K.H. Schleifer, \& W.B. Whitman (eds) 2009. Bergey's Manual of Systematic Bacteriology. Volume 3. 2nd edition. Springer-Verlag, New York. 
Yasuda, K. \& T. Kitao 1980. Bacterial flora in the digestive tract of prawn, Penaeus japonicus Bate. Aquaculture 19: 229- 234.

Zanetti, S., T. Spanu, A. Deriu, L. Romano, L. A. Sechi \& G. Fadda 2001. In vitro susceptibility of Vibrio spp. isolated from the environment. International Journal of Antimicrobial Agents 17: 407-409. 